\title{
Radiosensitization of cervical cancer xenografts by arsenic trioxide and the role of VEGF and Ku70
}

\author{
Qinlan Ren • Jeremy Tey • Xiaoyu Li • Yu Wu • \\ Hongbin Deng $\cdot$ Lan Han
}

Received: 7 December 2011 / Accepted: 28 December 2011 /Published online: 1 February 2012

(C) Springer-Verlag 2012

\begin{abstract}
Objective The aim of this study is to explore the effect of arsenic trioxide $\left(\mathrm{As}_{2} \mathrm{O}_{3}\right)$ on radiosensitivity in cervical carcinoma xenografts and the possible underlying mechanisms of vascular endothelial growth factor (VEGF) and Ku autoantigen protein $\mathrm{p} 70(\mathrm{Ku} 70)$.

Methods The tumor-bearing C57BL/6mouse model was established by injecting U14 cervical carcinoma cells into the right infra-axillary dermis of 40 mice. The mice were randomized into four groups: (1) control group (peritoneal injection, $0.2 \mathrm{ml}$ of $0.9 \%$ normal saline); (2) $\mathrm{As}_{2} \mathrm{O}_{3}$ only group (peritoneal injection, $2.0 \mathrm{mg} / \mathrm{kg}, 0.2 \mathrm{ml} \mathrm{As} \mathrm{O}_{3}$ ); (3) irradiation only group (peritoneal injection $0.9 \% \mathrm{NS}, 0.2 \mathrm{ml}+6 \mathrm{MeV}$
\end{abstract}

Qinlan Ren and Jeremy Tey contributed equally to this work.

Q. Ren $(\bowtie) \cdot$ H. Deng $\cdot$ L. Han

Department of Oncology, The First Affiliated Hospital,

Chongqing Medical University,

1\# You Yi Road, Yuzhong District,

Chongqing 400016, China

e-mail: renqlwu@yahoo.com.cn

Q. Ren·J. Tey

Department of Radiation Oncology, National University Hospital,

National Cancer Institute of Singapore,

Singapore, Singapore

X. Li

Institute of Radiation Medicine, Chongqing Medical University, Chongqing, China

Y. Wu

Department of Neurology, The Second Affiliated Hospital,

Chongqing Medical University,

Chongqing, China electron beam, $10 \mathrm{~Gy}$ ); and (4) $\mathrm{As}_{2} \mathrm{O}_{3}+$ irradiation group (peritoneal injection, $2.0 \mathrm{mg} / \mathrm{kg}, 0.2 \mathrm{ml} \mathrm{As}_{2} \mathrm{O}_{3}+6 \mathrm{MeV}$ electron beam, $10 \mathrm{~Gy}$ ). The mice were sacrificed 25 days after randomisation. U14 cervical tumors from the mice were harvested and weighed. Response to treatment using radiation and/or $\mathrm{As}_{2} \mathrm{O}_{3}$ was evaluated by extent of inhibition (i.e., growth inhibition rate) of tumor growth. VEGF and $\mathrm{Ku} 70$ mRNA expression and protein levels were evaluated by RTPCR and immunohistochemistry, respectively.

Results $\mathrm{As}_{2} \mathrm{O}_{3}+$ irradiation was found to significantly increase the inhibition of tumor growth. The growth inhibition rates in $\mathrm{As}_{2} \mathrm{O}_{3}$ only, irradiation only, and $\mathrm{As}_{2} \mathrm{O}_{3}+$ irradiated groups were $10.48 \%, 30.30 \%$, and $73.15 \%$, respectively $(\mathrm{p}<0.05)$. The combination also significantly downregulated the expression of VEGF and Ku70 in irradiated cervical carcinoma xenografts as compared to the control group, $\mathrm{As}_{2} \mathrm{O}_{3}$ only group, or irradiation only group $(\mathrm{p}<0.05)$.

Conclusions Arsenic trioxide effectively sensitizes the cervical carcinoma xenografts to ionizing irradiation. Downregulation of the expression of VEGF and Ku70 is likely to play an important role.

Keywords Arsenic trioxide - Cervical carcinoma . Radiosensitivity

\section{Introduction}

Cervical cancer is the most commonly diagnosed gynecological malignancy worldwide, and radiation therapy is a critical component in its management. Patients with early stage cervical cancer can be treated with radical hysterectomy or definitive radiotherapy; and those with locally advanced 
diseases are usually treated with concurrent chemoradiation, either as a primary or an adjuvant modality after surgery $[1,2]$. The addition of concurrent chemotherapy to curative dose of radiotherapy can significantly improve the outcome in terms of disease control and overall survival; however, prognoses of patients with locoregionally advanced cervical cancer remained suboptimal [3-6]. Furthermore, high dose radiation is associated with a number of side effects such as radiation cystitis and proctitis, vaginal stenosis, and ovarian dysfunction $[7,8]$. Strategies to further improve therapeutic ratio are clearly needed.

Arsenic trioxide $\left(\mathrm{As}_{2} \mathrm{O}_{3}\right)$ is a naturally occurring substance that has been used in medicine for more than 2,400 years. It has been used to treat a variety of conditions including cancer $[9,10] . \mathrm{As}_{2} \mathrm{O}_{3}$ has been proven efficacious in the treatment of acute promyelocytic leukemia (APL) with limited adverse effects [11-13]. It has been demonstrated that $\mathrm{As}_{2} \mathrm{O}_{3}$ can affect cellular signal transduction pathways and cross-talks of signal molecules which include downregulation of $\mathrm{Bcl}-2$ protein, activation of caspase, direct mitochondrial damage, promotion of tubulin polymerization [14], and some of the abovementioned mechanisms are involved in radiosensitization. Furthermore, the synergestic effects of $\mathrm{As}_{2} \mathrm{O}_{3}$ with radiation have been preliminarily reported in vitro and in vivo $[15,16]$. The effects of $\mathrm{As}_{2} \mathrm{O}_{3}$ on cervical cancer cells were previously suggested [17]. Nevertheless, whether $\mathrm{As}_{2} \mathrm{O}_{3}$ can enhance the therapeutic effect of radiotherapy and the mechanism(s) of its potential radiosensitizing effect has not been adequately addressed in cervical cancer. In an in vitro study, we have demonstrated the effect of $\mathrm{As}_{2} \mathrm{O}_{3}$ on radiosensitization in a cervical cancer cell line HeLa [18]. The aim of this study is to evaluate the effect of $\mathrm{As}_{2} \mathrm{O}_{3}$ on radiosensitivity in cervical carcinoma xenografts, as well as to explore the potential mechanism of $\mathrm{As}_{2} \mathrm{O}_{3}$ in radiosensitization.

\section{Materials and methods}

Animal and tumor models

Three to four weeks old C57BL/6 female mice with average weight $17-20 \mathrm{~g}$ were obtained from the Experimental Animal Center of Chongqing Medical University (qualification no. SCXK [YU]-2007001). The mice were housed at the Children's Hospital of Chongqing Medical University Animal Center and had free access to food and water and were kept on a 12-h light cycle. U14 human cervical cancer cell lines were obtained from the Institute of Pathophysiology, Chongqing Medical University. Cell culture media, fetal bovine serum, cell culture-grade buffers, and glucose were from Hyclone Inc. $\mathrm{As}_{2} \mathrm{O}_{3}$ was from Sigma Inc. and stored at room temperature. U14 cells were cultivated in RPMI 1640 supplemented with 5\% fetal bovine serum, $1 \% \mathrm{~L}$-glutamine, and $0.1 \%$ genramycin.

Mice were acclimated at least 5 days before any experiments. U14 xenografts were generated by subcutaneous (s.c.) implantation of $1 \times 10^{6} \mathrm{U} 14$ human cervical cancer cells suspended in $0.1 \mathrm{ml}$ RPMI_1640 into the right axilla of each mouse. The mice with U14 xenografts were included into the experiment when the shortest tumor diameter reached $6 \mathrm{~mm}$. Forty mice were randomly allocated into four groups of ten mice: (1) control group, (2) irradiation only group, (3) $\mathrm{As}_{2} \mathrm{O}_{3}$ only group, and (4) $\mathrm{As}_{2} \mathrm{O}_{3}+$ irradiation group.

\section{Radiotherapy and tumor inhibition assay}

Xenografts in the two irradiated groups received a single dose of 10 Gy using $6 \mathrm{MeV}$ electron beam with a dose rate of $4.0 \mathrm{~Gy} / \mathrm{min}$ (VARIAN ${ }^{\circledR} 2300 \mathrm{C} / \mathrm{D}$ ). Animals were sacrificed 20 days after irradiation. Tumor issues were isolated from mice and weighed to calculate the growth inhibition rate with the formula below:

Growth inhibition rate $=$ (average weight of xenografts in control groups - average weight of xenografts in irradiation groups $) /$ (average weight of xenografts in control groups) $\times 100$

\section{RT-PCR}

Total cellular RNAs were extracted from samples using TRIzol reagent (Invitrogen ${ }^{\circledR}$, Carlsbad, USA). First-strand synthesis was performed using the SuperScript ${ }^{\mathrm{TM}}$ firststrand synthesis system (Invitrogen ${ }^{\circledR}$, Carlsbad, USA) according to the manufacturer's instructions. All PCR reactions were carried out using an ABI Prism 7700 Sequence Detection system. The following primers and probes labeled with 5'-FAM and 3'-TAMRA were used to amplify vascular endothelial growth factor (VEGF) and $\mathrm{Ku}$ autoantigen protein $\mathrm{p} 70(\mathrm{Ku} 70)$.
VEGF Primer1: 5'-TTGTGCTCTACCTACCTCCAC-3'; Primer2: 5'-AATGCTTTCTCCGCTCTG-3'; Ku70 Primer1: 5'-TCTTGGCTGTGGTGTTCTATGGC-3'; Primer2: 5'-TCTTCTAGCTTGCTGGATTCCTC-3'.

Immunohistochemistry

The expression of VEGF and Ku70 were determined in deparaffinized, formalin-fixed section from PBS-treated U14 xenografts. Paraffin-embedded tissues were sectioned into $5 \mu$ sections. The sections were incubated in methanol/ 
$\mathrm{H}_{2} \mathrm{O}_{2}$ for 30 min to inhibit the endogenous peroxidase activity, washed with PBS for $5 \mathrm{~min}$, and then blocked with normal goat serum for $20 \mathrm{~min}$ at room temperature. The sections were incubated with antibodies against VEGF and $\mathrm{Ku} 70$ (Santa Cruz Biotechnology Inc) overnight at $4^{\circ} \mathrm{C}$, then with biotinylated secondary antibody for $1 \mathrm{~h}$ at room temperature and avidin-conjugated peroxidase for $45 \mathrm{~min}$ at room temperature. The sections were washed three times with PBS between each step. Peroxidase was stained with diaminobenzidine $(1 \mathrm{mg} / \mathrm{mL})$ and $\mathrm{H}_{2} \mathrm{O}_{2}$ for $5 \mathrm{~min}$ and washed with tap water for $10 \mathrm{~min}$. The sections were counterstained with hematoxylin for $1 \mathrm{~min}$. PBS was used as a negative control instead of primary antibody. Slides were analyzed using a well-established semiquantitative scoring method ranging from negative (-) to strong positive $(+++)$ [negative $(-)$ : no positive cells; weak positive $(+)$ : cells were stained yellow and the proportion of positive cells was under $25 \%$; medium positive $(++)$ : cells were stained brown and the proportion of positive cells was between $26 \%$ and $50 \%$; and strong positive $(+++)$ : cells were stained tan and the proportion of positive cells was above 50\%].

\section{Statistical analysis}

Data are expressed as means \pm standard deviation, and statistical significance was assessed by the Student's $t$ test. All tests were performed at least three times independently. A value of $p<0.05$ was set as the threshold for statistical significance for all study outcomes.

\section{Results}

Animal tumor models were successfully established in 40 mice about 6 days after implantation. The weight of tumor in $\mathrm{As}_{2} \mathrm{O}_{3}$ only group, irradiation only group, and $\mathrm{As}_{2} \mathrm{O}_{3}+$ irradiation group was all reduced as compared to the control group. The growth inhibition rate in $\mathrm{As}_{2} \mathrm{O}_{3}$ only group, irradiation only group, and $\mathrm{As}_{2} \mathrm{O}_{3}+$ irradiated group were $10.48 \%, 30.30 \%$, and $73.15 \%$, respectively $(p<0.05)$ (Table 1). Growth inhibition rate was significantly higher in mice treated with $\mathrm{As}_{2} \mathrm{O}_{3}+$ irradiation as compared to those in the control group or treated with $\mathrm{As}_{2} \mathrm{O}_{3}$ or radiation only.

\section{Expression of VEGF and $\mathrm{Ku} 70$ mRNA}

The expression of VEGF and Ku70 mRNA was significantly downregulated in the $\mathrm{As}_{2} \mathrm{O}_{3}+$ irradiation group compared with the irradiation only group, $\mathrm{As}_{2} \mathrm{O}_{3}$ only group, or the control group (Figs. 1 and 2). VEGF expression rate was $33.47 \%$ and $\mathrm{Ku} 70$ expression rate is $36.79 \%$ in the $\mathrm{As}_{2} \mathrm{O}_{3}+$ irradiation group. In semiquantitative analysis, the relative
Table 1 Comparison of the tumor weight in experimental groups $(\bar{x} \pm s, n=10)$

\begin{tabular}{lll}
\hline Group & Tumor weight $(\mathrm{g})$ & Inhibitory rate (\%) \\
\hline Control & $8.78 \pm 3.12$ & - \\
$\mathrm{As}_{2} \mathrm{O}_{3}$ & $7.86 \pm 2.93$ & 10.48 \\
Irradiation & $6.12 \pm 2.85$ & 30.30 \\
$\mathrm{As}_{2} \mathrm{O}_{3}+$ irradiation & $2.35 \pm 1.56^{*}, * *, * * *$ & 73.15 \\
\hline
\end{tabular}

$* p<0.05$, compared with $\mathrm{As}_{2} \mathrm{O}_{3}$ group

$* * p<0.05$, compared with irradiation group

$* * * p<0.05$, compared with control group

concentrations of VEGF and $\mathrm{Ku} 70$ mRNA in the $\mathrm{As}_{2} \mathrm{O}_{3}+$ irradiation group were found to be much lower than other groups $(p<0.05)$ (Tables 2 and 3$)$.

Expression of VEGF and Ku70 protein in cervical cancer xenograft

The VEGF protein was detected primarily in the cytoplasm of tumor cells and Ku70 protein expression was mainly localized in the nucleus on immunohistochemistry. Analysis showed that the expression intensity of VEGF and Ku70 protein was medium to strongly positive in the control group, $\mathrm{As}_{2} \mathrm{O}_{3}$ only group, and irradiation only group, as compared to weak to strongly positive in the $\mathrm{As}_{2} \mathrm{O}_{3}+$ irradiation group. The positive rates of the expressions of the VEGF and $\mathrm{Ku} 70$ proteins in $\mathrm{As}_{2} \mathrm{O}_{3}+$ irradiation group were significantly lower compared with other groups $(p<0.05)$ (Table 4).

\section{Discussion}

Radiotherapy is one of the most important treatment modalities for cervical cancer, and over $80 \%$ cervical cancer patients receive radiation in their course of management.

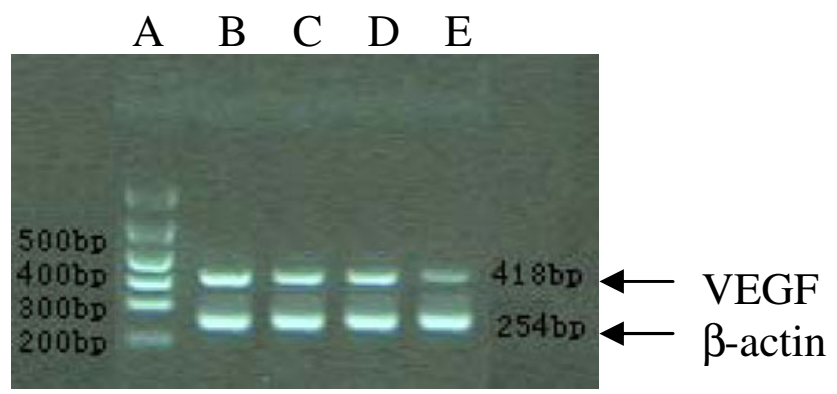

Fig. 1 Agarose electrophoresis of $\beta$-actin, VEGF mRNA in experimental groups. Lane A, Marker; Lane $B$, Control group; Lane $C, \mathrm{As}_{2} \mathrm{O}_{3}$ group; Lane D, Irradiation group; Lane $E, \mathrm{As}_{2} \mathrm{O}_{3}+$ irradiation group 


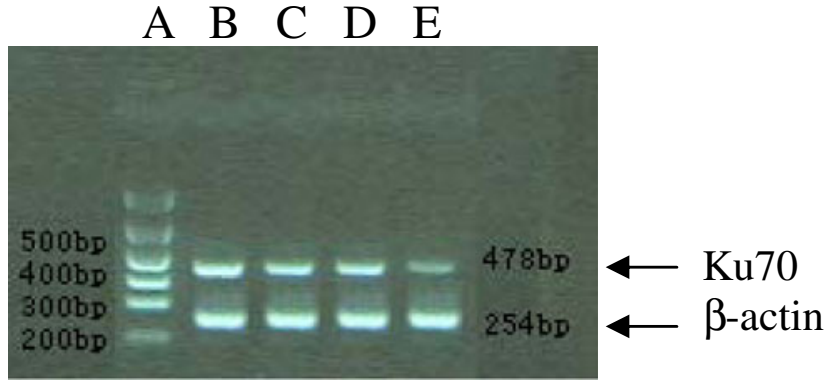

Fig. 2 Agarose electrophoresis of $\beta$-actin, Ku70 mRNA in experimental groups. Lane A, marker; Lane $B$, control group; Lane $C, \mathrm{As}_{2} \mathrm{O}_{3}$ group; Lane $D$, irradiation group; Lane $E, \mathrm{As}_{2} \mathrm{O}_{3}+$ irradiation group

The addition of chemotherapy to radiation has significantly improved the prognosis of cervical cancer patients; however, vthe outcome after concurrent chemoradiation remains suboptimal [3-6]. Clearly, strategies for further improvement of therapeutic ratio in the management of cervical cancer with radiation-based treatment are needed.

$\mathrm{As}_{2} \mathrm{O}_{3}$ is an agent successfully employed in the treatment of APL with limited side effects [11-13]. It was found to induce growth inhibition and apoptosis in solid tumors $[19,20]$. Recently, some investigators reported that $\mathrm{As}_{2} \mathrm{O}_{3}$ can cause DNA damage, oxidative stress, and mitochondrial dysfunction. $\mathrm{As}_{2} \mathrm{O}_{3}$ acts as in the $\mathrm{G}_{1}$ or at $\mathrm{G}_{2} / \mathrm{M}$ phases of the cell cycle and sensitizes tumor cells to ionizing radiation $[15,21,22]$. In an in vivo study reported by Kumar et al., $\mathrm{As}_{2} \mathrm{O}_{3}$ enhanced the therapeutic efficacy of radiation treatment of oral squamous carcinoma while protecting bone [15]. $\mathrm{As}_{2} \mathrm{O}_{3}$ was also reported to sensitize renal cancer cells, osteosarcoma cells, and GBM stem cells to radiation therapy in vitro studies [23-25].

Our previous experiences have demonstrated the synergistic effects of arsenic trioxide and radiation in cervical cancer cells HeLa through increasing the apoptosis rate and significantly downregulating the expression of bcl2 [18]. The results of the current in vivo study confirmed

Table 2 Semiquantitative analysis of VEGF mRNA in experimental groups

\begin{tabular}{lll}
\hline Group & Relative content & Expressing rate (\%) \\
\hline Control & $0.732 \pm 0.0324$ & 100.00 \\
$\mathrm{As}_{2} \mathrm{O}_{3}$ & $0.674 \pm 0.0268$ & 92.08 \\
Irradiation & $0.653 \pm 0.0247$ & 89.21 \\
$\mathrm{As}_{2} \mathrm{O}_{3}+$ irradiation & $0.245 \pm 0.0229^{*}, * *, * * *$ & 33.47 \\
\hline
\end{tabular}

${ }^{*} p<0.05$, compared with $\mathrm{As}_{2} \mathrm{O}_{3}$ group

$* * p<0.05$, compared with irradiation group

$* * * p<0.05$, compared with control group
Table 3 Semiquantitative analysis of Ku70 mRNA in experimental groups

\begin{tabular}{lll}
\hline Group & Relative content & Expressing rate (\%) \\
\hline Control & $0.685 \pm 0.0246$ & 100.0 \\
$\mathrm{As}_{2} \mathrm{O}_{3}$ & $0.643 \pm 0.0372$ & 93.87 \\
$\mathrm{Irradiation}$ & $0.676 \pm 0.0328$ & 98.69 \\
$\mathrm{As}_{2} \mathrm{O}_{3}+$ irradiation & $0.252 \pm 0.0294 *, * *, * * *$ & 36.79 \\
\hline
\end{tabular}

$* p<0.05$, compared with $\mathrm{As}_{2} \mathrm{O}_{3}$ group

${ }^{* *} p<0.05$, compared with irradiation group

$* * * p<0.05$, compared with control group

our previous findings. We found that tumor weight was significantly reduced and growth inhibition rate was significantly higher in the group of mice that received the combined treatment, as compared to those in control or received either radiation or $\mathrm{As}_{2} \mathrm{O}_{3}$. The magnitude of the control clearly indicated a synergestic rather than an additive effect of the combined radiation $+\mathrm{As}_{2} \mathrm{O}_{3}$, thus suggested that when used as a radiosensitizer, $\mathrm{As}_{2} \mathrm{O}_{3}$ can significantly improve the therapeutic efficacy.

Furthermore, we explored the possible mechanisms of radiosensitization involving VEGF and Ku70, two molecular markers known to affect radiosensitivity[26-32]. The molecular mechanisms of the radiosensitization effect of $\mathrm{As}_{2} \mathrm{O}_{3}$ were elucidated by evaluating the expression of VEGF and Ku70 with RT-PCR and immunohistochemistry. VEGF plays a significant part in the formation of the tumor blood vessels and stimulates the growth and metastasis of tumor [26, 27]. Elevated serum VEGF levels are associated with poor response and a shorter time to progression in patients with cervical cancer treated with radiotherapy [28]. There is also evidence that patients with cervical cancer with VEGF overexpression have a lower 5-year survival when treated with radiotherapy alone [29].

Table 4 Expression intensity and positive rate of VEGF and $\mathrm{Ku} 70$ protein in experimental groups

\begin{tabular}{|c|c|c|c|c|}
\hline \multirow[t]{2}{*}{ Group } & \multicolumn{2}{|c|}{ Expression intensity } & \multicolumn{2}{|c|}{ Positive rate $(\%, \bar{x} \pm s)$} \\
\hline & VEGF & $\mathrm{Ku} 70$ & VEGF & $\mathrm{Ku} 70$ \\
\hline Control & $++\sim+++$ & $++\sim+++$ & $69.8 \pm 3.95$ & $70.2 \pm 3.46$ \\
\hline $\mathrm{As}_{2} \mathrm{O}_{3}$ & $++\sim+++$ & $++\sim+++$ & $60.4 \pm 3.87$ & $68.6 \pm 3.23$ \\
\hline Irradiation & $++\sim+++$ & $++\sim+++$ & $55.9 \pm 3.52$ & $69.5 \pm 3.87$ \\
\hline $\begin{array}{l}\mathrm{As}_{2} \mathrm{O}_{3}+ \\
\quad \text { irradiation }\end{array}$ & $+\sim+++$ & $+\sim+++$ & $22.4 \pm 2.98 *, * *, * * *$ & $29.3 \pm 3.28^{*}, * *, * * *$ \\
\hline
\end{tabular}


$\mathrm{Ku} 70 / 80$ is a heterodimer that was first identified as a component of non-homologous end joining, an error-prone pathway that is involved in the repair of DNA double-strand breaks. Some studies suggested that overexpression of survivin might enhance double-strand break repair capability thereby radioresistance in human squamous cell carcinoma cell line KB by upregulating Ku70 [30]. Zhang et al. reported that histone deacetylase inhibitors could modulate cellular responses to ionizing radiation by downregulation of $\mathrm{Ku} 70$ [31]. Evidence suggests that $\mathrm{Ku} 70$ expression is inversely related to radiation sensitivity. Wilson et al. [32] reported that a lower Ku70 expression increased radiosensitivity and improved survival in cervical cancer patients treated with radiotherapy. Thus, the lower the expression of $\mathrm{Ku} 70$, the higher radiation sensitivity and the better radiotherapeutic efficacy.

The immunohistochemistry of our study showed that the expression of VEGF and $\mathrm{Ku} 70$ mRNA in $\mathrm{As}_{2} \mathrm{O}_{3}+$ irradiation group was significantly less than the irradiation only, $\mathrm{As}_{2} \mathrm{O}_{3}$ only or the control group. In semiquantitative analysis, relative concentration of VEGF and $\mathrm{Ku} 70$ mRNA in the $\mathrm{As}_{2} \mathrm{O}_{3}+$ irradiation group was much lower than other groups $(p<0.05)$. The downregulation of VEGF and $\mathrm{Ku} 70$ expression significantly increased growth inhibition rate in the $\mathrm{As}_{2} \mathrm{O}_{3}+$ irradiation group compared with other groups. In summary, our results show that $\mathrm{As}_{2} \mathrm{O}_{3}$ sentisizes cervical cancer cells to ionizing radiation. Downregulation of VEGF and Ku70 is likely to play an important role.

Despite of our encouraging findings, the radiosensitizing effect of $\mathrm{As}_{2} \mathrm{O}_{3}$ on cervical cancer requires clinical confirmation. Concurrent chemoradiation is the current standard for the treatment of locally advanced cervical cancer. Synergistic effects between cisplatin-based chemotherapy agents and $\mathrm{As}_{2} \mathrm{O}_{3}$ have also been suggested in a number of studies, but with different mechanism as compared to our current finding $[33,34]$. Recent clinical data showed that $\mathrm{As}_{2} \mathrm{O}_{3}$ could achieve high efficacy and good tolerance at long-term follow-up. The toxicity profile was mild and reversible whether $\mathrm{As}_{2} \mathrm{O}_{3}$ was used alone or combined with other drugs[12, 13, 35, 36]. It would be interesting to explore whether $\mathrm{As}_{2} \mathrm{O}_{3}$ further improves the therapeutic effects of cervical cancer treated with cisplatin-based chemotherapy with concurrent radiation. Furthermore, various mechanisms have been suggested for the radiosensitizing effect of $\mathrm{As}_{2} \mathrm{O}_{3}$. Clearly, other potential mechanisms in addition to the downregulation of VEGF and $\mathrm{Ku} 70$ await further investigation.

Disclaimer This research was conducted in accordance with the Declaration of Helsinki and with the Guide for Care and Use of Laboratory Animals as adopted and promulgated by the United National Institutes of Health. All experimental protocols were approved by the Review Committee for the Use of Human or Animal Subjects of Chongqing Medical University.
Acknowledgments This work was fully supported by a grant from Chongqing Municipal Health Bureau of China (no. 2008-2-31).

Conflict of interest The authors declare no conflict of interest.

\section{References}

1. Park JH, Kim YS, Ahn SD, Choi EK, Shin SS, Kim YT, Kim YM, Kim JH, Yi SY, Nam JH (2010) Concurrent chemoradiotherapy or radiotherapy alone for locally advanced cervical cancer in elderly women. Tumori 96:959-965

2. Kantardzic N (2010) Concurrent chemoradiation for cervical cancer: results of five randomized trials. Med Arh 64:368-370

3. Eifel PJ, Winter K, Morris M, Levenback C, Grigsby PW, Cooper J, Rotman M, Gershenson D, Mutch DG (2004) Pelvic irradiation with concurrent chemotherapy versus pelvic and para-aortic irradiation for high-risk cervical cancer: an update of radiation therapy oncology group trial (RTOG) 90-01. J Clin Oncol 22:872-880

4. Pearcey R, Brundage M, Drouin P, Jeffrey J, Johnston D, Lukka H, MacLean G, Souhami L, Stuart G, Tu D (2002) Phase III trial comparing radical radiotherapy with and without cisplatin chemotherapy in patients with advanced squamous cell cancer of the cervix. J Clin Oncol 20:966-9725

5. Whitney CW, Sause W, Bundy BN, Malfetano JH, Hannigan EV, Fowler WC Jr, Clarke-Pearson DL, Liao SY (1999) Randomized comparison of fluorouracil plus cisplatin versus hydroxyurea as an adjunct to radiation therapy in stage IIB-IVA carcinoma of the cervix with negative para-aortic lymph nodes: a Gynecologic Oncology Group and Southwest Oncology Group study. J Clin Oncol 17:1339-1348

6. Grigsby PW, Heydon K, Mutch DG, Kim RY, Eifel P (2001) Long-term follow-up of RTOG 92-10: cervical cancer with positive para-aortic lymph nodes. Int J Radiat Oncol Biol Phys 51:982-987

7. Azad SK, Choudhary V (2010) Treatment results of radical radiotherapy of carcinoma uterine cervix using external beam radiotherapy and high dose rate intracavitary radiotherapy. J Cancer Res Ther 6:482-486

8. Ghezzi F, Cromi A, Serati M, Uccella S, Formenti G, Bogani G, Vanoli P (2011) Radiation-induced bowel complications: laparoscopic versus open staging of gynecologic malignancy. Ann Surg Oncol 18:782-791

9. Raju GP (2011) Arsenic: a potentially useful poison for Hedgehogdriven cancers. J Clin Invest 121:14-16

10. Takahashi S (2010) Combination therapy with arsenic trioxide for hematological malignancies. Anticancer Agents Med Chem 10:504-510

11. Mathews V, George B, Chendamarai E, Lakshmi KM, Desire S, Balasubramanian P, Viswabandya A, Thirugnanam R, Abraham A, Shaji RV, Srivastava A, Chandy M (2010) Single-agent arsenic trioxide in the treatment of newly diagnosed acute promyelocytic leukemia: long-term follow-up data. J Clin Oncol 28:3866-3871

12. Ghavamzadeh A, Alimoghaddam K, Rostami S, Ghaffari SH, Jahani M, Iravani M, Mousavi SA, Bahar B, Jalili M (2011) Phase II study of single-agent arsenic trioxide for the front-line therapy of acute promyelocytic leukemia. J Clin Oncol 29:2753-2757

13. Au WY, Kumana CR, Lee HK, Lin SY, Liu H, Yeung DY, Lau JS, Kwong YL (2011) Oral arsenic trioxide-based maintenance regimens for first complete remission of acute promyelocytic leukemia: a 10-year follow-up study. Blood 118:6535-6543

14. Sumi D, Shinkai Y, Kumagai Y (2010) Signal transduction pathways and transcription factors triggered by arsenic trioxide in leukemia cells. Toxicol Appl Pharmacol 244:385-392 
15. Kumar P, Gao Q, Ning Y, Wang Z, Krebsbach PH, Polverini PJ (2008) Arsenic trioxide enhances the therapeutic efficacy of radiation treatment of oral squamous carcinoma while protecting bone. Mol Cancer Ther 7:2060-2069

16. Ho SY, Chen WC, Chiu HW, Lai CS, Guo HR, Wang YJ (2009) Combination treatment with arsenic trioxide and irradiation enhances apoptotic effects in U937 cells through increased mitotic arrest and ROS generation. Chem Biol Interact 179:304-313

17. Yu J, Qian H, Li Y, Wang Y, Zhang X, Liang X, Fu M, Lin C (2007) Arsenic trioxide $\left(\mathrm{As}_{2} \mathrm{O}_{3}\right)$ reduces the invasive and metastatic properties of cervical cancer cells in vitro and in vivo. Gynecol Oncol 106:400-406

18. Ren QL, Wu YZ, Chen XP, Dai XB, Deng HB (2007) Radiosensitization effect of arsenic trioxide on human cervical carcinoma cell line HeLa. J Clin Rehab Tis Eng Res 11:8189-8192, in Chinese

19. Chen GQ, Shi XG, Tang W, Xiong SM, Zhu J, Cai X, Han ZG, Ni JH, Shi GY, Jia PM, Liu MM, He KL, Niu C, Ma J, Zhang P, Zhang TD, Paul P, Naoe T, Kitamura K, Miller W, Waxman S, Wang ZY, de The H, Chen SJ, Chen Z (1997) Use of arsenic trioxide (As2O3) in the treatment of acute promyelocytic leukemia (APL): I. As2O3 exerts dose-dependent dual effects on APL cells. Blood 89:3345-3353

20. Ai Z, Pan H, Suo T, Lv C, Wang Y, Tong S, Liu H (2011) Arsenic oxide targets stem cell marker CD133/prominin-1 in gallbladder carcinoma. Cancer Lett 310:181-187

21. Chiu HW, Lin JH, Chen YA, Ho SY, Wang YJ (2010) Combination treatment with arsenic trioxide and irradiation enhances cell-killing effects in human fibrosarcoma cells in vitro and in vivo through induction of both autophagy and apoptosis. Autophagy 6:353-365

22. Li Y, Qu X, Qu J, Zhang Y, Liu J, Teng Y, Hu X, Hou K, Liu Y (2009) Arsenic trioxide induces apoptosis and G2/M phase arrest by inducing $\mathrm{Cbl}$ to inhibit PI3K/Akt signaling and thereby regulate p53 activation. Cancer Lett 284:208-215

23. Tomuleasa C, Soritau O, Kacso G, Fischer-Fodor E, Cocis A, Ioani H, Timis T, Petrescu M, Cernea D, Virag P, Irimie A, Florian IS (2010) Arsenic trioxide sensitizes cancer stem cells to chemoradiotherapy. A new approach in the treatment of inoperable glioblastoma multiforme. J BUON 15:758-762

24. Chiu HW, Lin W, Ho SY, Wang YJ (2011) Synergistic effects of arsenic trioxide and radiation in osteosarcoma cells through the induction of both autophagy and apoptosis. Radiat Res $175: 547-560$
25. Su Y, Wang X, Xu W, Xue L, He C, Yang D, An R (2011) Arsenic trioxide increases the sensitivity of 786-0 renal carcinoma cells to radiotherapy. Cancer Invest 30(2):114-118

26. Gajanin V, Krivokuća Z, Kostić K, Gajanin R, Sladojević I (2010) Significance of vascular endothelial growth factor expression in skin melanoma. Vojnosanit Pregl 67:747-754

27. Goncharuk IV, Vorobjova LI, Lukyanova NY, Chekhun VF (2009) Vascular endothelial growth factor exression in uterine cervical cancer: correlation with clinicopathologic characteristics and survival. Exp Oncol 31:179-181

28. Bachtiary B, Selzer E, Knocke TH, Pötter R, Obermair A (2002) Serum VEGF levels in patients undergoing primary radiotherapy for cervical cancer: impact on progression free survival. Cancer Lett 179:197-203

29. Kang JO, Hong SE (2004) The prognostic effect of VEGF expression in squamous cell carcinoma of the cervix treated with radiation therapy alone. J Korean Med Sci 19:693-697

30. Jiang G, Ren B, Xu L, Song S, Zhu C, Ye F (2009) Survivin may enhance DNA double-strand break repair capability by up-regulating $\mathrm{Ku} 70$ in human KB cells. Anticancer Res 29:223-228

31. Zhang F, Zhang T, Teng ZH, Zhang R, Wang JB, Mei QB (2009) Sensitization to gamma-irradiation-induced cell cycle arrest and apoptosis by the histone deacetylase inhibitor trichostatin $\mathrm{A}$ in non-small cell lung cancer (NSCLC) cells. Cancer Biol Ther $8: 823-831$

32. Wilson CR, Davidson SE, Margison GP, Jackson SP, Hendry JH, West CM (2000) Expression of Ku70 correlates with survival in carcinoma of the cervix. Br J Cancer 83:1702-1706

33. Zhang N, Wu ZM, McGowan E, Shi J, Hong ZB, Ding CW, Xia P, Di W (2009) Arsenic trioxide and cisplatin synergism increase cytotoxicity in human ovarian cancer cells: therapeutic potential for ovarian cancer. Cancer Sci 100:2459-2464

34. Li H, Zhu X, Zhang Y, Xiang J, Chen H (2009) Arsenic trioxide exerts synergistic effects with cisplatin on non-small cell lung cancer cells via apoptosis induction. J Exp Clin Cancer Res 28:110

35. Wang H, Chen XY, Wang BS, Rong ZX, Qi H, Chen HZ (2011) The efficacy and safety of arsenic trioxide with or without all-trans retinoic acid for the treatment of acute promyelocytic leukemia: a meta-analysis. Leuk Res 35:1170-1177

36. Murgo AJ (2001) Clinical trials of arsenic trioxide in hematologic and solid tumors: overview of the National Cancer Institute Cooperative Research and Development Studies. Oncologist 6 (Suppl 2):22-28 